\title{
Rehabilitation of a Marginal Mandibulectomy Patient using a Modified Neutral Zone Technique: A Case Report
}

\author{
Gürel PEKKAN ${ }^{1}$ \\ Canan HEKIMOGLU² \\ Nesrin SAHIN ${ }^{3}$

\begin{abstract}
${ }^{1}$ Department of Dentistry, Training and Research Hospital, Dumlupinar University, Kutahya, Turkey
${ }^{2}$ Department of Prosthodontics, Faculty of Dentistry, Hacettepe University, Sihhiye, Ankara, Turkey
\end{abstract} \\ ${ }^{3}$ Private Practice, Ankara, Turkey
}

\begin{abstract}
Anterior edentulous areas usually display unusual soft tissue configurations and compromised bone support in patients with marginal mandibulectomy. There are several treatment modalities for these patients. A removable partial denture may be the treatment of choice. Maximum stability of the partial denture base for mandibulectomy patients may be accomplished by the application of the neutral zone concept, which helps providing stability to the base. This case report describes the fabrication of a removable partial denture for a patient with marginal mandibulectomy using a modified neutral zone technique.
\end{abstract}

Key Words: denture stability, mandibulectomy, neutral zone technique.

\section{INTRODUCTION}

In marginal mandibulectomy patients with anterior defected areas, the edentulous segment usually displays unusual soft tissue configurations and compromised bone support. In large defects, the lack of attached mucosa and the obliteration of vestibules may require a vestibuloplasty and skin graft (1). Unless a vestibuloplasty is performed and denture bearing surfaces are created, bands of scar tissue are easily irritated by the prosthesis. In small defects, when a cuspid has been retained, mastication is effectively restored. Furthermore, the placement of implants in the symphyseal region provides the necessary support, retention and stabilization for the prostheses.

Removable partial denture may be a preference for patients submitted to marginal mandibulectomy. Removable partial denture frameworks should follow routine parameters for framework design related to support stability, retention, reciprocation and minor and major connectors (2). If a removable partial denture is the selected treatment modality, maximum stability of the partial denture base may be accomplished by two basic procedures (3). The first is obtained by a double impression procedure. The second is by eliminating lateral and horizontal forces caused by the functional movements of the lips, cheeks and tongue. This may be accomplished with use of the neutral zone technique. The neutral zone must be evaluated as an important factor for accomplishing denture stability and retention. However, it had been stated that the neutral zone has not been given enough importance in the literature (4).

This case report describes the fabrication of a removable partial denture for a patient with marginal mandibulectomy and an anterior edentulous area using a modified neutral zone technique.

\section{CASE REPORT}

A 41-year-old Caucasian male patient with chief

Correspondence: Dr. Gürel Pekkan, Dumlupinar University, Training and Research Hospital, Department of Dentistry, Tavsanli Yolu, 10 Km., 43270 Kutahya, Turkey. Tel: +90-274-265-2031. Fax: +90-274-265-2277. e-mail: gurelp@gmail.com 
complaint of enlargement of the right mandibular side was examined at the Faculty of Dentistry of Hacettepe University. The enlargement of the right mandible was obvious extraorally. Additionally, the mass expanded the buccal and lingual bone plates intraorally. Mandibular left central and lateral incisors, right central and lateral incisors, canine and first premolars had third degree mobility in this region. The other present teeth were: Mandibular arch - right first and second molars and left canine, first premolar and second molar. Maxillary arch - right central and lateral incisors, canine, second premolar, second molar and third molar; left central and lateral incisors, canine, first and second premolars and second molar. Radiographic examination showed expansions of the cortical bone plates and erosion of root interfaces. Fine-needle aspiration biopsy was performed. The diagnosis was multilocular cystic ameloblastoma, which is an aggressive, benign epithelial odontogenic tumor that has three different types. Cystic ameloblastoma is originated mostly from dentigerous cysts and rarely from other odontogenic cysts (5).

The lesion was excised together with the mobile teeth in this region at the Department of Oral Surgery. The patient was referred to the Department of Prosthodontics for denture fabrication (Fig. 1). Master casts were made with hard gypsum (Kristal Alçı San. Ltd, Ankara, Turkey) and mounted in a parallelometer (Bego, Parasko, Bremen, Germany) for treatment planning. Removable partial denture framework and rest seats were planned. It was decided that the use of a modified neutral zone technique would be appropriate for increasing function and stability, because neutral zone

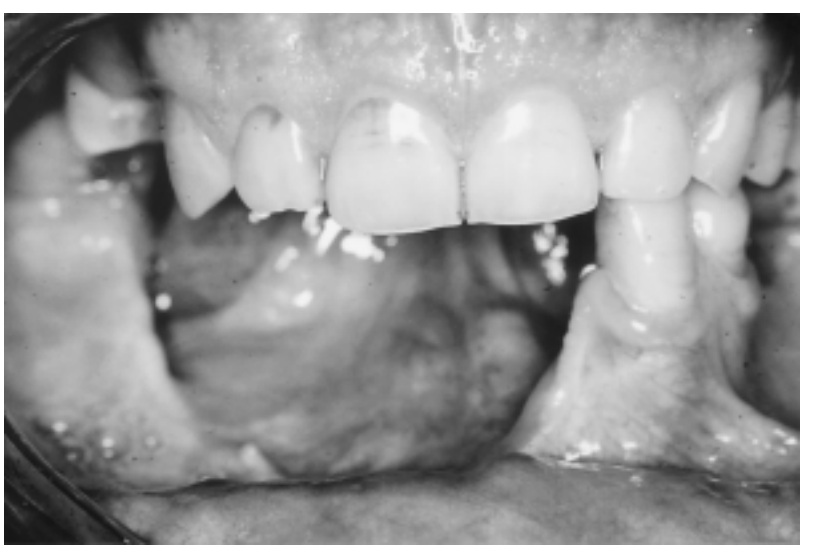

Figure 1. Intraoral view of the patient. technique for mandibulectomy patients with anterior defects has been shown to improve esthetic, support of soft tissues, function and articulation (1).

Rest seats were prepared on the teeth intraorally. Mandibular and maxillary impressions were made using irreversible hydrocolloid (Blueprint Cremix; Dentsply, Detrey, England). A metal framework for the mandible was cast (Fig. 2), tried in the patient's mouth and the required adjustments were made.

The red modeling plastic impression compound (Impression Compound, Kerr, Salerno, Italy) was softened, rolled in U shape and combined with the lower cast framework for functional impression, which would determine the neutral zone region. The framework with the red modeling plastic impression compound rolled on its edentulous portion was placed into mouth. The functional movements made by the patient were recorded in the impression (6). After setting, the material was trimmed down by $2 \mathrm{~mm}$. The green modeling plastic impression compound (Kerr) was softened and loaded on red compound. Still, functional movements were made in the same manner by the patient and modeling plastic impression compound was trimmed by 0.5-1 mm. A final functional impression was corrected using zinc oxide impression material (SS White Impression Paste, Gloucester, England) (Fig. 3). A mould of the edentulous portion was obtained and the edentulous segment of the master cast was eliminated. The cutsurfaces were grooved for additional retention.

The framework and impression were returned to the cast model and were luted with sticky wax (Kerr, Romulus, MI, USA) to avoid displacement during box-



Figure 2. Cast metal framework for the mandible. 
ing and pouring procedures. So, the buccal and lingual surfaces of the edentulous region were recorded in the form of neutral zone, and the other regions of the basal seats were recorded in an anatomic form (Fig. 4). A tongue, lip and cheek matrices were represented for preservation of the neutral zone on the cast model. The matrices were made in silicone in putty consistence (Speedex; Coltene/Whaledent Inc., Mahaw, NJ, USA). The artificial teeth (Major, Prodotti Dentari, Italy) were arranged in the edentulous region with guidance of the silicone matrices.

The trial dentures were inserted into the mouth and interferences were eliminated with the movements of lips, cheeks and tongue. After deciding that the trial dentures were stable and retentive, intercuspal relation was checked and thereafter esthetic, phonetic and

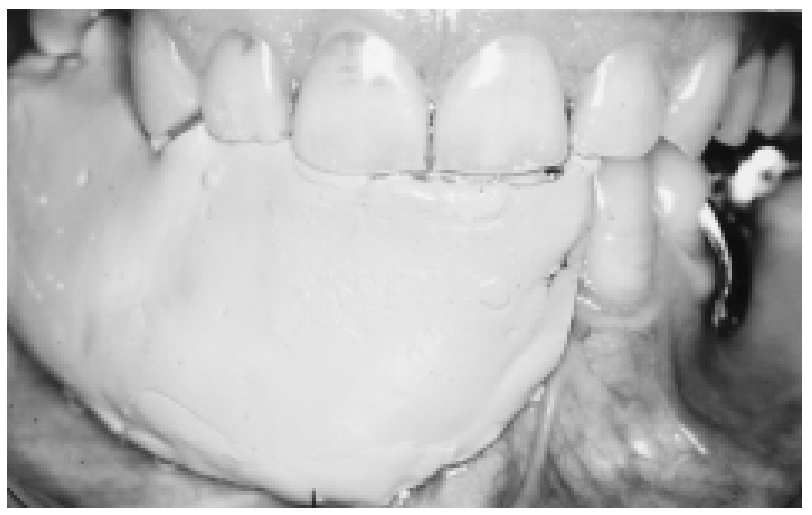

Figure 3. Final functional impression with zinc oxide impression material.

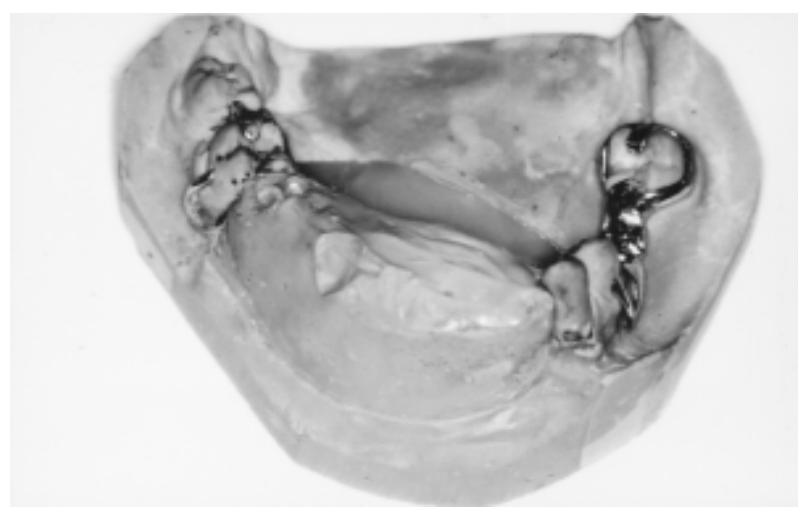

Figure 4. View of the cast model showing the formation of the anterior edentulous region in neutral zone. functional requirements were fulfilled.After processing, finishing and polishing, the denture was delivered to the patient and tested for stability, retention, intercuspal relation, esthetics and phonetics (Fig. 5).

\section{DISCUSSION}

The soft tissues that form the internal and external surfaces of the denture greatly affect and influence the stability of the dentures, and help determining the peripheral borders, tooth position, and external contours of the dentures $(7,8)$. The forces developed through muscular contraction during mastication, speaking and swallowing are directed against the dentures (9). This will either help stabilizing them or tend to dislodge them (3). The magnitude and duration of retentive forces directly influence the longevity and health of the tooth.

Techniques designed to define the neutral zone for the purposes of tooth location may help provide increase stability, any denture must have enough retention to resist the momentary displacing forces caused by imbalanced muscle action $(7,10)$. Neutral zone is the area in the mouth where the forces of the tongue pressing outward are neutralized by the forces of cheeks and lips pressing inward during function (3).

The perioral musculature, especially the buccinator muscle is the outer limit of the neutral zone. The length, strength and position of this muscle are the main determinants. Another important muscle is orbicularis oris muscle. The whole dental arch, the teeth with their alveolar process, the tongue, the lips and the cheeks should be evaluated regarding directional pressures

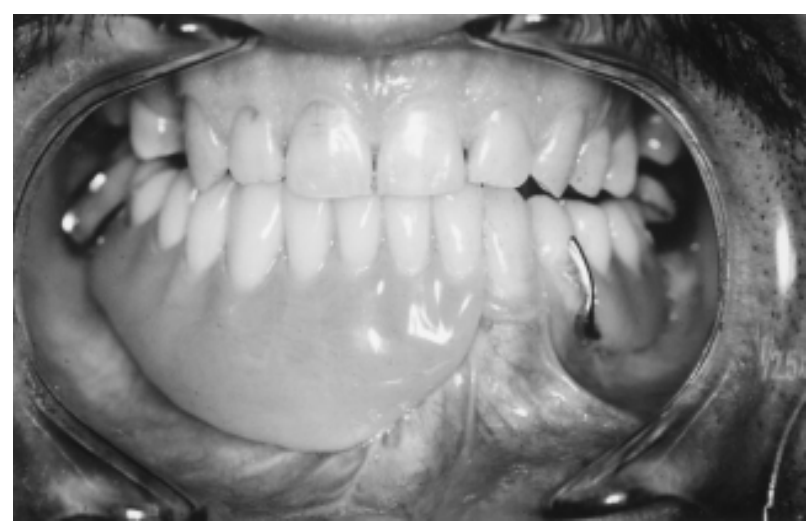

Figure 5. Intraoral frontal view showing the definitive removable partial denture. 
exerted by these anatomical factors to the dental arch. The position and angulation of the teeth is the best indicator for determining the current neutral zone in dentulous patients (4). The positive effects of the neutral zone technique are not only to accomplish the mentioned statements for the denture and the patient, but also to act as a critical determinant of facial profile.

Removable partial dentures fabricated according to the neutral zone technique for mandibulectomy patients with anterior edentulous areas are believed to enhance esthetics and provide support for the lower lip and cheek. It will frequently lead to improved articulation of speech and enhance the control of saliva (1). In the case hereby reported, mastication, speech, esthetics, saliva control and facial profile were considerably enhanced. These results indicate that the application of neutral zone concept for the patients who undergo maxillectomy or mandibulectomy may help stability of the denture base, and also improve functions.

Accordingly, conventional removable partial dentures for marginal mandibulectomy patients with unusual soft tissue configurations that are constructed using the neutral zone impression technique are able to provide stability, esthetics and comfort.

The neutral zone may be altered by orthodontics, elimination of noxious habits, myofunctional therapy, reduction of tongue size, surgical lengthening of the buccinator band, vestibuloplasty and orthognatic surgery (4). However, it must be emphasized that the effect of surgical approach should be evaluated.

\section{RESUMO}

Áreas anteriores edêntulas apresentam configurações incomuns de tecido mole e suporte ósseo comprometido em pacientes submetidos a mandibulectomia marginal. Há diversas modalidades de tratamento para estes pacientes. A instalação de uma prótese parcial removível pode ser o tratamento de escolha. Máxima estabilidade da base da prótese parcial para pacientes submetidos a mandibulectomia pode ser obtida pela aplicação do conceito da zona neutra, o que auxilia na estabilização da base. Este relato de caso descreve a fabricação de uma prótese parcial removível em um paciente com mandibulectomia marginal utilizando uma modificação da técnica da zona neutra.

\section{REFERENCES}

1. Beumer JB III, Curtis TA, Marunick MT. Maxillofacial rehabilitation: prosthodontic and surgical considerations. 2nd ed. St. Louis: Ishiyaku Euromerica; 1996.

2. Taylor TD. Clinical maxillofacial prosthetics. Chicago: Quintessence; 2000.

3. Wee AG, Cwynar RB, Cheng AC. Utilization of the neutral zone technique for a maxillofacial patient. J Prosthodont 2000;9:2-7.

4. Beresin VE, Schiesser FJ. The neutral zone in complete dentures. J Prosthet Dent 2006;95:93-100 (Read before the Academy of Denture Prosthetics, Washington, DC. Reprinted with permission from J Prosthet Dent 1976;36:357-367).

5. Shafer WG, Hine MK, Levy BM. A textbook of oral pathology. 4th ed. Philadelphia: WB Saunders; 1983.

6. Kursoglu P, Ari N, Calikkocaoglu S. Using tissue conditioner material in neutral zone technique. N Y State Dent J 2007;73:40-42.

7. Lamb DJ. Problems and solutions in complete denture prosthodontics. London: Quintessence Publishing Co Ltd; 1993.

8. Gahan MJ, Walmsley AD. The neutral zone impression revisited. Br Dent J 2005;198:269-272.

9. Makzoume JE. Morphologic comparison of two neutral zone impression techniques: a pilot study. J Prosthet Dent 2004;92:563-568.

10. Lynch CD, Allen PF. Overcoming the unstable mandibular complete denture: the neutral zone impression technique. Dent Update 2006;33:21-22,24-26.

Accepted November 21, 2006 